BMC JOURNAL OF SCIENTIFIC RESEARCH A Multidisciplinary Peer Reviewed Research Journal ISSN: 2594-3421 (Print), 2773-8191 (Online)

\title{
Class, Culture and Principles: Evaluating the Chinese Cultural Revolution on the Basis of its Aims and Strategies Dharma Bahadur Thapa* \\ E-mail: dharma.thapa@bimc.tu.edu.np
}

Received: Aug. 1, 2021, Accepted: Dec. 15, 2021

\begin{abstract}
Culture in any society is inherited from the past as a form of tradition. It is an automatic and unconscious process. It is usually taken as supra-class unifying category which binds a community. China during Mao proclaimed that old culture serves the interests of the exploiting class and therefore the proletariat as an emerging class should struggle against it and impose its own culture. On this premise 'the Great Proletarian Cultural Revolution'was launched. Its aim was to 'prevent the restoration of capitalism 'by revolutionizing people's thinking to realize the communist goal of classless society. It lasted from 1966 to 1976, however, debates still continue regarding its aims, principles and practices and achievements or the damages it caused. This article attempts to explore what it actually wanted to accomplish and what strategies and measures were employed to materialize these aims. For this purpose it uses the documents published by the Communist Party of China during that period as the primary sources and judges them on the basis of Marxist socialist principles. The paper reaches to the conclusion that the Cultural Revolution adopted principles, policies and methods which accord with Marxism.
\end{abstract}

Key word: Bourgeois, Cultural Revolution, Collective Interest, Personal-Interest

\section{Definition of Culture and the Cultural Revolution: An Introduction}

Culture signifies various but equally viable concepts. Jenks (2005) examines the concept of culture from ideological, sociological and linguistic perspectives and advances that "it is the ways of life of a people, their beliefs, rituals and customs" (p.10). Marxism emphasizes on the class nature of culture. It is accepted as a component of superstructure founded on the socio-economic base. Marx (1977) holds that the class which has the means of material production at its disposal has control at the same time over the means of mental production (p.47). In other words, culture, as a form of mental production, is determined by the class which holds the politico-economic power. Thus the ruling class culture imposes false consciousness on the working class which prevents them from understanding the real social relations. Drawing upon the Marxist concept of the dominant class deciding the cultural composition of any society, Williams (1977) formulates the tri-dimensional formation of cultural dynamism, namely, dominant, residual and emergent (pp. 122,23, 24). The dominant portion is what determines the basic character of any society whereas the residual refers to remnants of the past. Emergent culture grows out of the dominant formation which contests and ultimately

\footnotetext{
* Mr. Thapa is Associate Professor in English at Birendra Multiple Campus (Tribhuvan University)
} 
has to supplant it to gain the dominant position. He posits that a new class is always the source of emergent cultural practice. That new class is the working class (p.124). This shows that culture is a dynamic and contested zone. It is historically associated with the dominance of the ruling class which the working class can challenge, alter and impose its own hegemony.

The Chinese Cultural Revolution (the CCR), which lasted from 1966 to 1976, was designated as the "Great Proletarian Cultural Revolution" (the GPCR). It aimed at preventing capitalist restoration in China by continuing the revolution under the dictatorship of the proletariat. It was founded on Maoist proposition (1977) that class struggles exist in the ideological and political realm in a socialist society and the danger of reversal to capitalism is real one (p. 409). It was argued that only initiation and active participation of the masses in the struggle against the capitalist roaders at the top level of the party can ensure the victory of the cause of communism. It was claimed that it accorded with and founded on the Marxist principles of communism.

The CCR continued for a decade before it was terminated after Mao's death and the subsequent arrest of so called gang of four. The post-Maoist Communist Party of China (CPC hereafter) evaluated the CR period as "catastrophe to the Party, state and the whole people" (Beijing Review, 1981 No. 27 p. 22).

Starting with a brief theoretical and political background and addressing views for and against it, the article attempts to explore aims, the principles adopted and practices executed during that period using the party publications as the sources of research. The study and analysis mainly relies on the articles of Peking Review (later Beijing Review) as resource materials of the period as they represent the party line.

\section{The Debate Continues: An Analysis of the Views on the Cultural Revolution}

The Chinese Cultural Revolution has provoked a huge body of debates, discussions assessments from various perspectives. Even after more than four decades of its formal termination, it still incites much heated academic and political and academic discussions as it did during the time of its inception. Weakland (1969) posits that its origin cannot be traced only in "orthodox Marxism" which assumes that "practice leads to attitudes" but ideas can "determine reality" (p. 14). He also establishes the resemblance between "the ways the Confucian culture assimilation and the Cultural Revolution" (p.19). Despite assessing the whole process of the CCR as "extremist in nearly all respects," he admits that its aim was the "inner remolding of the entire population into persons who will be wholly selfless in service to society" (p.41).

Han (2000) has extensively surveyed the impact of the CCR on various aspects of Chinese society. His findings are based on his investigation in the Jimo County in the Shandong Peninsula where he was born, brought up and educated through the period of the CCR (p.3). He claims that it empowered ordinary Chinese people to struggle against privileges of the party and government officials in various ways. He maintains, "The Cultural Revolution threatened this previous pattern in Chinese political life. It 
empowered the ordinary people to challenge the tight control over political resources by party leaders at the different levels. That is why most party leaders condemned it and most rural people supported it" (p.54).

Xing (2001) contrasts the promotions of socialist values like cooperatives, public ownership and control over the means of production planned wealth distribution and elimination of political and economic inequalities as the achievements of the CCR with the market oriented capitalist restoration of Deng Xiao ping in the post-Maoist era (pp. 137-38). He refutes the claim that the CCR was a total failure and argues that it raised people's consciousness about political and social rights (p.158). Unger's article (2007) on the CCR foregrounds the phases, mass participation and effects on the various groups like high school and university students, government officials, country, town and ethnic minorities (p. 121). Ning (2018) examines the CCR from the perspectives of the "Western-Trained Intellectuals" and concludes that intellectuals were "either eventually victimized in Maoist campaign or took advantage of political winds for personal advancement" (p.312). Hao (2018) argues that "the dominant political thinking during the Cultural Revolution supported antagonistic and fallacious logic, dictatorial, dehumanizing and violent thoughts and behaviour in the service of purism and a fundamental ideology" (p.295). Paul (2019) insists that the GPCR mobilized the masses to construct socialism and it is not easy for the capitalist rulers to stamp out its impact in people's memory (p. 6).

The forthcoming section of the article explores the principles, aims and strategies employed in the Cultural Revolution using the party and government publications as the sources of study. It attempts to probe what end it actually aimed to accomplish and how much they concur with Marxist principles.

\section{Aims, Principles and Strategies of the Cultural Revolution in China}

At least two contemporary events prompted Mao to launch the Cultural Revolution. One was the capitalism oriented reforms adopted by Nikita Khrushchev in the former USSR in the post-Stalin era and the other was the hold of the reformists in the leading body of the CPC itself. Their political line diverged over the question of the course of socialist revolution and construction. They took the seizure of the state power and nationalization of means of production as the final end of the revolution whereas Mao took it as the beginning of more important and complex form of revolution in the realm of superstructure which includes culture, politics, literature and people's beliefs and habits. For him the country-wide victory was "only the first step in a long march of ten thousand li" (PR 1968, No. 48 p. 9). Grounding himself on Marxist principles of socialism and class struggle, Mao (1977) advances:

The class struggle between the proletariat and the bourgeoisie, the class struggle between the various forces, and the class struggle between the proletariat and the bourgeoisie in the ideological field will still be protracted and tortuous and at times even very sharp. The 
proletariat seeks to transform the world according to its own world outlook, and so does the bourgeoisie. In this respect, the question of who will win out, socialism or capitalism is not really settled yet. (p.409)

Mao takes ideological conflict as a form of class struggle. As a component of superstructure political or ideological can have decisive impact on the socio-economic base. According to him the relationship between the base and the superstructure is not mechanical but dialectical. In his philosophical essay "On Contradiction” Mao (1971) posits:

True, the productive forces, practice and the economic base generally play the principal and decisive role; whoever denies this is not a materialist. But it must also be admitted that in certain conditions, such aspects as the relations of production, theory and the superstructure in turn manifest themselves in the principal and decisive role. (p.116) The decision of the CCP of August 8, 1966 formally proclaims the aims, theoretical premises and strategies to be adopted of the "Great Proletarian Cultural Revolution." It advances that "The Great Proletarian Cultural Revolution now unfolding is a great revolution that touches people to their very soul" ( $P R$ 1966, No. 33 p. 6). The document states:

Although the bourgeoisie has been overthrown, it is still trying to use the old ideas, culture, customs and habits of the exploiting classes to corrupt the masses, capture their minds and endeavour to stage a comeback. The proletariat must do just the opposite: it must meet head-on every challenge of the bourgeoisie in the ideological field and use the new ideas, culture, customs and habits of the proletariat to change the mental outlook of the whole society (emphasis added, p.6)

The CCR aimed to transform the society according to the proletarian outlook, by displacing the old culture of the bourgeoisie and all the exploiting classes. Culture, habits, customs and ideas form parts of ideology or superstructure. In the relationship between economic base and superstructure, the determining position keeps shifting. The document assumes that after the completion of the revolution, the role of the superstructure becomes pivotal in the transformation of the society. If the bourgeois culture and ideas are let loose, it can hamper the proletarian transformation of the society. A society cannot remain in the ideological vacuum. The idea of revolution touching the people to their very soul indicates the type of strategy that was to be employed in the movement. It outlines its immediate objective as the struggle against and those persons in authority who are taking the capitalist road and transform education, literature and art and all other parts of superstructure that do not correspond to the socialist economic base (p.6).

The document indicates that persuasive rather than coercive methods were adopted 
among the working class masses. They were encouraged to air their views by means of "big character posters and great debate" (p.7). The document stresses that "the only method is for the masses to liberate themselves" (p.7). Trusting the masses, relying on them and respect their initiative was the directive (p.8). The directive bases itself on mass line which means "from the masses and to the masses" (p.11). It did not allow leaders to represent the masses and work on their behalf. Differing views were taken as "unavoidable, necessary and beneficial" (p.10).

The aim of the CR was, as the document has emphasized, to transform the DNA of the thinking and practice of the whole society to a new direction by taking a radical departure from the existing conditions. It was to transform world outlook of the society. It could not be realized by simply issuing directives and proclaiming rules and regulation from above. It could be possible only with active participation of the whole society. The CCR adopted mass line which allowed unrestricted initiative and participation of the working class. In other words it was not a top-down movement. It was defined as "a mass movement from below" (PR 1967, No. 24 p. 5). So it was a bottom-top movement.

\section{Valued Practices and Promoted Values}

Ideas and directives put forth by Mao were used as guiding principles throughout the CR. Among them three of his articles- "In Memory of Norman Bethune," "Serve the People" and "The Foolish Old Man Who Removed the Mountains" played a significant part in enhancing the revolutionary teachings (PR 1966, No. 5 p.7). "Serve the People" is a speech delivered by Mao Tse-tung on September 8, 1944 at a memorial meeting for Chang Szu-teh who is said to have died for people's interest (PR 1967, No. 2 p. 6). Mao valorises his martyrdom as being weightier than Mount Tai (p. 6). It is illustrated for its maxim of "the spirit of dedicating oneself wholly to the liberation of the people and working entirely in the in the people's interests ... without any thought of self” (p. 7). The article "In Memory of Norman Bethune" commemorates the untimely death of Norman Bethune, the Canadian doctor, while voluntarily serving in the Chinese revolution. Given on December 21, 1936, Mao, in the speech urges party members to learn true communist spirit from Bethune ( $P R$ 1967, No. 8 p.5). The article illustrates "the spirit of internationalism" and priority of public over self interests (p.7). In other words it represents the spirit of "utter devotion to other without any thought of self and absolute selflessness" (p.6).

"The Foolish Old Man Who Removed the Mountains" is the text of "the concluding speech made by Chairman Mao at the Seventh National Congress" of the CPC on "June 11 1945" (PR 1967, No. 12 p. 9). This is a brief Chinese tale which, as the title suggests, relates the story of a single minded old man who succeeds in removing the two peaks of mountains which obstructed the sunlight. The old man is used to symbolize the Chinese people struggling against the internal and external enemies. It was interpreted as "a great classical document of communist education and one of the most fundamental required 
readings . . . in establishing communist world outlook" (p. 10). Values it promotes are: trust in the masses, reliance on the masses and close integration with the masses (p. 13). It aims to imbue the people with the confidence that difficulties can be removed and victory gained (p.12).

The overemphasized publicity and importance given to these articles like gospels indicates the kind of the cultural values the CCR aimed to promote in the Chinese society. It promoted radical Marxist values like glorification of the public cause and denigration of the self interests, the spirit of proletarian internationalism, valorisation of the working classes and strong faith in communist aims and principles.

One has to contrast these aims against capitalistic cultural values to understand the ideology of the CCR. Capitalist culture places self-interest above everything. It is the driving force of capitalist political economy. Public interests are subordinated to private interests. Apparently, private interest means the interest of every individual but in essence it means and serves the self interests of big bourgeoisie. Old culture and habit of thinking naturalize and promote self interest of the capitalist class where there is no place for the interest of the working class. The CCR seems to reverse this state of thing and organize the society on altruistic basis which places public interest above self-interest. This kind of selflessness is not possible in capitalism because self-interest is the foundation of the capitalist society. This becomes possible if the whole society is structured in such a way that its members by habit value public interest above selfinterest. This kind of culture is certainly new. Every emergent culture faces obstacles and resistances in the beginning and there is the feeling of uneasiness, too. The extract below shows the importance given to the struggle against one's own interest:

In what does oldness of the old ideology of the exploiting classes lie? It lies essentially in "self- interest," means looking at the world from the viewpoint of everything for one's self, for self-interest. The selfishness of the exploiting classes is natural soil for the growth of capitalism . . . an ideological virus that disintegrates the socialist publicly owned economy and subverts the dictatorship of the proletariat. (PR 1967, No. 42 p. 14)

Targeting "self-interest" as a major part of the movement might sound preposterous. But it was taken as a matter of tantamount importance. Self-interest is not confined to the interest of oneself. In its extended form it sees the fulfilment of the interest of one's family, community or any kind of narrow circle justifiable. It encourages people to undermine the interest of the larger community. Self-interest even of a cadre was taken as breeding ground for capitalism because it promotes desire for luxury, greed and corruption. If fulfilment of self interest becomes the motto of leaders and cadres, the whole society learns the same value and begins to vie for property accumulation, profitable position and publicity for oneself becomes the sole purpose of everyone which ultimately results in class polarization and degeneration of socialist revolution and construction. On the global scale it leads stronger nations to pursue the policy of 
chauvinism and imperialism. Contrary to this, if selflessness becomes the guiding and dominant culture of the society, it encourages its members to think the interest of others first and help promote wider public cause which ultimately benefits the individuals as well.

Capitalism and socialism are diametrically opposed to each other in their aims and priorities regarding the acquisition and accumulation of private property. Amount of wealth is regarded as the precondition and measurement of prosperity and progress and individuals are encouraged to accumulate as much as they can at the cost of the public interest. Under socialism public wealth is promoted and surplus wealth of an individual is taken as damaging to the public interest. To promote public cause "material incentives" like bonus for the workers were criticised as "a hot-bed in which the concept of private ownership breeds and a poison and which corrupts people's minds" and as a form of "self-interest" (Yi, PR 1970, No. 21 p. 15).

Related with the promotion of public interest over the self is the attempt to restrict "bourgeois right" which was interpreted as detrimental to the socialist cause. Lian (1975) explains:

The principle of "to each according to his work" still plays a role in the historical period of socialism and we will continue to implement it. But we should recognize that this principle, after all, is not a communist principle, and will be abolished in the future. The ultimate aim of the proletariat is to establish a communist society where the principle of "from each according to his ability, to each according to his needs" is applied. (PR 1975, No. 12 p. 15)

"Bourgeois right" here does not mean the right the bourgeoisie claims over the 'private' property. It is a form of self-interest even a worker can claim for the fruit of his labour. It sounds logical to claim the fruit of one's labour as the policy of payment "according to his work" permits. But he may not need all of his income for personal consumption which, if not channelled to the public good, can breed the condition for accumulation which results in the emergence of the capitalist class. Under capitalism the surplus income promotes the need and desire for accumulation. For socialism to enter into communism, the policy of "according to his needs" has to be implemented. During the CCR bourgeois right, "to each according to his work," was not abolished but the discussion of restriction on it had started and the movement was guided to this direction. Capitalism promotes consumer culture. It has to create artificial needs in the society for its survival. Sign value overrules the use value. Market creates needs and promotes luxury and extravagance. This general rule of capitalism works everywhere including today's China. But the CCR advocated "hard struggle and plain living style" for the CPC members and people. Cadres were urged to retain the life style of an ordinary worker ( $P R$ 1968, No. 13 p.16). In addition to other advantages, this helped them to maintain close ties with the working class. "Three-in-one" revolutionary committees with the involvement of the representatives of cadres, members from the armed forces 
and masses were formed to carry out the movement. It was believed that it would enable them to strike deep roots among the masses ( $P R$ 1968, No. 14 p. 6).

The culture of a society is determined by character of the dominant class. In a feudal society the nobility owns the property enjoys privileges and high social prestige on the patrilineal basis. Capitalism broke away from this culture and established the dominance based on money. The CCR attempted to replace power of birth and capital with labour and revolutionary spirit. In other words it laid down principles and carried out practices which privileged the working class in political, social, economic and educational arena. Establishing the proletariat "in the position of absolute domination in all spheres of ideology and culture" was taken as the policy of prime importance ( $P R$ 1968, No. 38 p. 16). Intellectuals and students were urged to integrate with the working class and learn from them and adopt the proletarian revolutionary world outlook (p. 16). This not only enabled them to learn from the practical experience and world outlook of the working class, but also helped the workers to learn from students and intellectuals and narrow down the gap between workers and intellectuals.

Related with the labour is the question of ownership. One can work for oneself or for collective interest. To work for oneself was taken as bourgeois practice whereas to take part in the "in collective labour, become one with the masses of workers and peasants and maintain revolutionary qualities of labouring people" was much emphasized practice ( $P R$ 1968, No. 42 p. 8). Labouring people or the revolutionary proletariat class was also regarded as the refreshing and reenergizing force. The article "Absorb Fresh Blood From the Proletariat" calls on the cadres to get inspired by the world conquering energy and enthusiasm of the proletariat ( $P R$ 1968, No. 43 p. 3). Live contact with the proletariat was regarded as the source of revolutionary inspiration and vigour.

Preference for city to country living is the general trend in the world because besides the availability of physical amenities, city life is associated with prestige and 'advanced' culture. But the CCR attempted to reverse this trend. Living in the socialist countryside was prioritized over town living which fostered integration and promotion of the country life. PR reports that some of the city people in Huining County in Kansu Province who were long divorced from labour, including a group of educated young people have gone to the countryside group after group and settled down (1968, No. 52 p. 4).

In building socialism policy of self reliance and public initiative was much emphasized and implemented. In his article Tsai (1969) quotes Mao's dictum, namely, maintaining independence and keeping the initiative in our own hands and relying on our own efforts as the only correct way for building socialism. He asserts that debts offered by imperialist are "predatory and reactionary" (PR 1969, No. 21 p. 16). Western countries amassed wealth and recorded progress through colonial occupation and expansion. As a big nation which suffered the humiliation of colonial occupation and plunder, to turn to the foreign power for assistance and mercy was similar to fall back to their snares. Although never totally negated foreign aid, China during the CCR practised and stressed self-reliance which boosted the nation's morale and socialist economy. 


\section{Conclusion}

The study and analysis of the documents issued during the Cultural Revolution in China on the basis of Marxist definition of culture enables one to draw certain points of conclusion about the major characteristics of culture the Communist Party of China intended to promote and the principles and methods it adopted to execute them. It was an emergent culture of the working class which attempted to strengthen and promote the socialist base by remoulding the world outlook of the entire society according to radical Marxist perspective. It was a movement based on and initiated by the masses, a bottomtop movement guided by Maoist maxim, namely, it is right to rebel. It encouraged people to participate in all affairs of the state policies and decisions. As an anti-bourgeois movement it advocated and endeavoured to instil socialist values like selflessness, supremacy of the public interest at the cost of self-interest and respect for labouring mass as the maker of history. It aimed and tried to create a society without bourgeoisie. It emphasized political and moral incentive instead of material encouragement. It encouraged plain living, hard struggle and the spirit of self reliance. Its purpose was to create an integrative and equitable society by eliminating not only the bourgeoisie but also the reducing the differences between peasants and workers, country and city and manual and intellectual labour. It struck all sorts of national narrow-mindedness and advocated internationalism based on equality, mutual respect and assistance and opposed all forms of domination of the weak by the strong. In a nutshell it exercised the hegemony of the working class and materialized the culture of the emergent class envisaged by Marxism.

The study shows that persuasive rather than coercive methods were preferred in the Cultural Revolution as the document itself proclaimed that the struggle against four olds should be conducted with people's initiation and consent. It had to deeply affect to the very core of their souls without which new socialist culture could not be instilled. The mass were encouraged to air their views freely through big character posters and speeches. They were also called on to study articles which contained socialist themes. Heroes who laid down their lives for the public causes were valorised as illustrations of desired conducts from the public. In brief, by guiding the society to the direction in which people could be freed from the shackles of private property, a radical rupture was attempted from the culture of the exploiting classes. In this sense the Cultural Revolution completely accorded with the Marxist goals, methods and principles.

\section{References}

Beijing Review. (1981, No. 27). "Questions of Party History." (10-39). p.22.

Han, D. (2000). The unknown cultural revolution: educational reforms and their impact on China's rural development. New York, Garland Publishing, Inc. www.wengewang.org.

Hao, Z. (2018). "Cultural Revolution Thinking in China: Its Development and Manifestation in Pingzhou County from Land Reform Onwards." Journal of Contemporary China. https://doi.org/10.1080/10670564.2018..1389039. (295-311) p.295 
Jenks, K. (2005). Culture. London and New York: Routledge.

Lian, H. (1975, No. 12). "The Proletariat Must Exercise Dictatorship Over the Bourgeoisie." Peking Review. (13-16). p.15.

Mao T. (1971). “On Contradiction.” Selected Readings from the Works of Mao Tsetung. Peking:

Foreign Language Press. (85-128).

Mao, T. (1977). "Correct Handling of Contradictions among the People." Selected Works of Mao Tsetung. Vol. V. Peking: Foreign Language Press. (384-421).

Marx, K. and Frederick Engels. (1977). "Feuerbach. Opposition of the Materialistic and

Idealistic Outlook." Selected Works. Vol. 1. Moscow: Progress Publishers. (16-80).

Ning W. (2018). "Bowing to Chairman Mao: Western-Trained Intellectuals and the State in the

Early PRC.” Journal of Contemporary China. Vol.27, Issue 110.

https://doi.org/10.1080/10670564.2018.1389042 (312-326) p.312.

Paul, J.M. (2019). “Preface.” In: Ching, Y.C. From Victory to Defeat. Paris: Foreign Language Press, p.6.

Peking Review. (1966, No. 5). "Be a Conscious Revolutionary.” (6-8). p.7.

Peking Review. (1966, No. 33). "Decision of the Central Committee of the Chinese Communist

Party Concerning the Great Proletarian Cultural Revolution.” (6-11). pp. 6, 7, 8, 10, 11.

Peking Review. (1967, No. 2). "Serve the People." (6-7). p. 6.

Peking Review. (1967, No. 2). "Maxims for Revolutionaries- "The Three Constantly Read Articles."" (7-8).pp. 7, 8.

Peking Review. (1967, No. 8). "In Memory of Norman Bethune.” (5-6). p. 5.

Peking Review. (1967, No. 8). "Study In Memory of Norman Bethune." (6-9). pp. 6,7.

Peking Review. (1967, No. 12). "Study The Foolish Old Man Who Removed the Mountains."

(9-14). pp. 9, 10, 12, 13.

Peking Review. (1967, No. 24). "A Great Strategic Measure.” (5-7). p. 5.

Peking Review. (1967, No. 42). “Combat Self-Interest, CCRiticize and Repudiate Revisionism” Is

the Fundamental Principal of the Great Proletarian Cultural Revolution." (14-15). p.14.

Peking Review. (1968, No. 13). "Feng Fu-sheng- P.L.A. Activist in Studying Chairman Mao's

Works" (14-16). p.16.

Peking Review. (1968, No. 14). "Revolutionary Committees Are Fine.” (6-7). p.6.

Peking Review. (1968, No. 38). "On the Re-Education of Intellectuals.” (16-17). p. 16.

Peking Review. (1968, No. 42). "Old and New Cadres on Taking Part in Collective Productive

Labour." (8-10). p. 8.

Peking Review. (1968, No. 42). "How a County Revolutionary Committee Revolutionizes Itself." (11-13). p. 11.

Peking Review. (1968, No. 43). "Absorb Fresh Blood From the Proletariat.” (3-7). p. 3.

Peking Review. (1968, No. 48). "Report to the Second Plenary Session of the Seventh Central

Committee of the Communist Party of China (March 5, 1949).” (3-9). p. 9.

Peking Review. (1968, No. 52). "We Also Have a Pair of Hands and Do Not Want To Lead an Idle Life in the City." (4-7). p. 7. 
Tsai, C. (1969, No. 21). "Our Country Is Now a Socialist Country Without Internal or External Debts." Peking Review. (15-17). p. 16.

Unger, J (2007). "The Cultural Revolution at the Grass Roots." The China Journal Vol. 1 https://www.researchgate.net/publication/290722949. (109-137) pp. 121.

Weakland, J.H. (1969). Cultural Aspects of China 's “Cultural Revolution.” California: Menatal Research Institute.

Williams, R. (1977). Marxism and Literature. Oxford New York: Oxford University Press.

Xing L. (2001). “The Chinese Cultural Revolution Revisited."The China Review, Vol. 1. No. 1 (137-165) pp. 137-38, 158.

Yi, K. (1970, No. 21). "Material Incentives" Are a Reaction to the Dictatorship of the Proletariat." Peking Review. (14-17). p.15. 